to be dropped for the present. Extra-mural work under the Joint Committee of the University and the Workers' Educational Association has made progress and the number of classes and students has increased. Prof. W. K. Hancock has been given lesve of absence to visit West Africa for a study of West African problems in continuance of his "Survey of British Commonwealth Affairs". Dr. O. Frisch of Copenhagen has been appointed a temporary member of the staff of the Physics Department.

\section{Social Services for Youth}

THE Board of Education has directed attention to a serious deficiency in our social services in a circular recently issued to the local education authorities for higher education in England and Wales, and a similar circular has been issued by the Secretary of State for Scotland to the education authorities in Scotland. These authorities are asked to take steps to set up local youth committees in their areas, and voluntary organizations and education authorities are called upon to combine in making real provision for the social and physical development of young persons between the ages of fourteen and twenty who have ceased full-time attendance at school. This neglected and elusive problem has been accentuated by war conditions- the black-out, the strain and disorganization of family life-and the Board of Education has now assumed a direct responsibility for juvenile welfare. The National Youth Committee has been appointed to advise them and a special branch of the Board of Education office has been organized to deal with grants and other administrative duties.

The new committees will place youth work on an equal basis with the rest of education. Sometimes they will be sub-committees of local authorities; others may represent all local interests including the local authority. Their task will be to work out an ordered policy, meeting both the immediate needs and indicating the lines of advance under more favourable conditions. Local education authorities are expected to see that the Committee is properly staffed and equipped with office accommodation, and they can assist financially by making grants towards the rent of buildings, salaries of full-time leaders, upkeep and maintenance of premises, including provision of equipment and instructors. The appointment of the National Youth Committee has been welcomed by the King in a message to the Prime Minister, in which His Majesty appeals to the public for volunteers to undertake the tasks of leadership and organization which these plans envisage, and an announcement asking for volunteers has already been made by the President of the Board of Education and the Secretary of State for Scotland at the request of the National Youth Committee.

\section{American Psychologists in War-time}

America believes in being forearmed. Already the American Association for Applied Psychology has devised a plan to mobilize psychologists to aid the Government in time of emergency as they did in 1918
(Science Service, Washington, D.C.). The chief problems to be considered are connected with the selecting and classifying of men according to their abilities, the selecting of promising recruits for military flying, treating those who break down under the strain of war and discipline, and keeping up the morale of armed forces and those at home. The human element and human 'nerves' are much more important now than in the War of 1914-18, although even then a considerable proportion of war casualties were 'nervous' cases.

At the meeting which discussed the matter there were representatives of the Army and Navy, the Public Health Service, and the Department of Justice. The armed services have already arranged to avoid in any future war the heavy psychological casualties of the last war. The first step has been to provide for the careful psychiatric examination of all new recruits, with an observation period in which any border-line cases might be weeded out or assigned to jobs where personality difficulties will be at a minimum. They are also discussing whether, by means parallel to those used by enemy agents to foment discord, psychologists could be used to promote good feeling and smooth out grievances.

\section{Aquaria Societies' Difficulties}

THE wartime difficulties of aquaria societies, especially those which maintain public aquaria, have not proved so disastrous as at first expected. The Scottish Aquarium Society, at a recent meeting, decided to produce a modified edition of its journal Scottish Aquarium Herald, as Mr. R. Kerr, the original editor, is serving in H.M. Navy. Brighton Aquarium recently acquired an attractive exhibit of 120 silver whiting (Gadus merl angus), as well as congers, anglers, spider crabs, ocean sunfish and an owl fish. The Carnegie Aquarium at Edinburgh is also managing to keep a full stock of exhibits, including herring. Manchester Zoo Aquarium has 41 specimens of Neon tetra on view in the tropical section, as well as a large electric eel. Dudley (Worcestershire) Zoo Aquarium recently received some claw-footed toads.

On the Continent, Paris Zoo Aquarium has distributed its fish to the Prince of Monaco's Aquarium at Monte Carlo and to private individuals, and its reptiles to Marseilles Zoo. The aquarium at Berlin Zoo has been broken up and closed and the reptiles destroyed. Hamburg Zoo has disposed of all its collection. Belle Vue (Manchester) Aquarium and Vivarium Society has decided to levy half the normal subscription and review the position again in six months' time.

\section{Archæological Discoveries of 1939 in Ireland}

ArCHAOLOGICAL excavations in the vicinity of Lough Gur, Co. Limerick, in the season 1939, it is claimed in a report in The Times of January 2, have obtained results of outstanding significance for Irish archæology. This area has now been under investigation for four consecutive seasons, thanks to the Government's scheme for the relief of unemployment ; 
and several sites have been examined, including three stone circles, a megalithic tomb, and a series of dwelling sites. The excavations have been carried out under the direction of Prof. Seán P. O'Riordain of the University of Cork. The principal site excavated in 1939 was a large and exceedingly wellpreserved stone circle on the western side of the lake, near the Bruff-Limerick road. Not only is this the best known prehistoric monument of the Lough Gur, but it is also said to be the finest stone circle in Ireland. It is built of large stones backed up by a huge bank of earth, and encloses a level, open internal space $155 \mathrm{ft}$. in diameter.

Here important finds of pottery were made, of which some afford evidence for a new chapter in Irish archæology. A reconstrueted vessel proved to be a 'beaker', the first of its kind to be found in Ireland. It belongs to the class of ceramic characteristic of the 'Beaker Folk', who reached Britain in the late neolithic or Early Bronze ages, but, it has been thought hitherto, did not reach Ireland. A further discovery of considerable interest is that of neolithic pottery of types found only sporadically in Ireland, except in the north-east. On the evidence of the finds, the circle is dated at approximately 1700 B.c., and its ritual purpose, that of a prehistoric temple, is regarded as definitely determined. In a group of neolithic houses on the peninsula of Knockadoon in Lough Gur, one, exceptionally well-constructed, is said to be the earliest house yet found in Ireland. It is $32 \mathrm{ft}$. long by $18 \mathrm{ft}$. wide. The lower part of the walls is of stone, the superstructure of wood and thatch-a type well known from various periods in northern Europe.

\section{Landscape Meteorology}

Mr. L. C. W. Bonacina's paper entitled "Landscape Meteorology and its Reflection in Art and Literature" (Quart. J. Roy. Meteor. Soc., 65, No. 282 ; October 1939) is a detailed study of the scenic aspect of clouds and weather, and an example of that co-operation between science and art which is one of the most interesting developments of culture during recent years. We welcome particularly the author's dictum that it is a mistake for the man of science to regard scenic values as altogether outside his province. It is equally to the point that the landscape artist will find additional enjoyment, and possibly also increased efficiency, if he studies the physics of meteorological effects. The later part of the paper is mainly devoted to descriptions of local and seasonal phenomena. One outstanding example is that of the night sky as seen from the high plateau of Bolivia, where the general aspect of the constellations is that of coloured stars.

Valuable as is this elaborate paper, the reader cannot help feeling how great is the difficulty of bringing the artistic and scientific aspects of a subject into one essay. The perceptive and reflective moods are alternate, and the literary technique for their simultaneous treatment has not been fully mastered. Indeed, we do not yet know if it can be mastered. If so, it will be by Ruskin re-incarnate in the world of to-day, with the same faculties of sight and expression but imbued with the culture of the present time.

\section{Malnutrition in South Africa}

AN informative survey of the state of nutrition of the peoples of South Africa is given by Ellen Radloff and T. W. B. Osborn in a pamphlet with the above title (Johannesburg: The Witwatersrand University Press, 1939. 2s.). South Africa has been spoken of as the most prosperous country in the world, which is a true statement for a minority of the European section. But South Africa is also a country of poor whites and poorer blacks, which is true for several millions of non-Europeans and several hundred thousands of Europeans. The principal dietary essentials for proper nutrition are discussed, with descriptions of the conditions that result when these are deficient. Tables are given of the vitamin content of common foodstuffs and of typical South African diets.

The basic ration scale recommended for adult Europeans at the Health Department's institutions appears to be ample and adequate, and is in striking contrast to the daily diet scale for adult native paupers in Cape Province, which consists of $1 \mathrm{oz}$. of fat (not butter) and $24 \mathrm{oz}$. of mealies. Remedies are suggested for the malnutrition that exists, which include improvement of the economic condition of the people, educating them to buy meat, milk, fruit and vegetables, and in rural communities providing more land for them to buy and improving their grade of cattle. A direct pharmacological approach to the question is also suggested by providing rations of essential salts and vitamins.

\section{Underground-and the City of the Future}

IN the Beama journal of November reference is made to Le Corbusier's city of the future consisting of dwellings, offices, and factories contained in huge blocks separated by gardens. One of the main features of this modern eity is the large part of its activity which takes place underground. Power stations, garages, warehouses and other public service buildings, as well as traffic routes for vehicles and pedestrians, would be constructed in this way. Already there exists a plan for the diversion of a large part of the Paris traffic, the underground routes for which were examined by the Minister of Public Works some years ago. Électricité published a report on this subject by M. Roger d'Arboville, professor of applied electricity in the well-known Ecole spéciale d'Architecture, on the lighting of underground traffic and pedestrian routes. He reviews the pragtice exemplified in some of the short subways in Paris, in the long road tunnel projected for 1941 under the Meuse, the mile-long roadway under the Eseaut at Antwerp and various railway tunnels in France and England.

M. d'Arboville discusses the question of the lighting of underground road tunnels both in actual road tunnels and in many tunnels which are projected. The ever-increasing density and speed of 